\title{
APLIKASI KOMPONEN UTAMA NON LINEAR (PRINCALS) PADA PENINGKATAN MUTU PENDIDIKAN TINGGI
}

\author{
${ }^{1}$ Anna Islamiyati, ${ }^{2}$ La Podje Talangko \\ 1,2 Jurusan Matematika FMIPA, Universitas Hasanuddin \\ Jl.Perintis Kemerdekaan KM. 10 Tamalanrea Makassar 90245 \\ Telp. (0411-585643 \\ anna_islamiyati@yahoo.com
}

\begin{abstract}
ABSTRAK
Sekarang ini mutu pendidikan di Indonesia masih rendah. Bahkan untuk kawasan Asia Tenggara saja, Indonesia sudah tertinggal dari negara tetangga seperti Malaysia dan Singapura. Ini sangat memprihatinkan, sehingga menjadi tugas bersama untuk mengkaji peningkatan mutu pendidikan khususnya pada pendidikan tinggi. Salah satu cara untuk peningkatan mutu pendidikan tinggi tersebut adalah dengan mengetahui faktor-faktor yang mempengaruhi prestasi belajar mahasiswa, baik faktor intern maupun faktor ekstern.
\end{abstract}

Faktor-faktor yang mempengaruhi prestasi belajar mahasiswa dapat diketahui dengan mengumpulkan berbagai informasi atau data, baik data yang berskala kuantitatif (interval atau rasio) maupun data yang berskala kualitatif (nominal atau ordinal). Untuk menyelesaikan kasus tersebut dapat digunakan Metode Analisis Komponen Utama Nonlinear (PRINCALS) yaitu suatu metode untuk mereduksi variabel dari data multivariabel berskala campuran secara simultan. Aplikasi data akan digunakan pada data mahasiswa di salah satu perguruan tinggi.

Kata kunci: analisis multivariat, mutu pendidikan tinggi, princals, dan skala campuran,

\section{PENDAHULUAN}

Perkembangan dalam dunia pendidikan, khususnya bagi negara Indonesia, sudah tertinggal dari negara tetangga seperti Malaysia dan Singapura. Hal tersebut sangat memprihatinkan, sehingga menjadi tugas bersama untuk mengkaji faktor-faktor yang dapat meningkatkan mutu pendidikan tinggi di Indonesia pada umumnya. Salah satu cara untuk meningkatkan mutu pendidikan tinggi tersebut adalah dengan mengetahui faktor-faktor yang mempengaruhi prestasi belajar mahasiswa, sebagai salah satu unsur civitas akademika dalam perguruan tinggi.

Prestasi belajar mahasiswa yang diukur dari Indeks Prestasi kumulatif (IPK) dapat dipengaruhi oleh banyak faktor, baik faktor internal maupun faktor eksternal. Sehingga, jenis data yang diperoleh di lapangan merupakan kasus data campuran, yaitu gabungan antara data kuantitatif dan kualitatif. Jika metode analisis yang digunakan tidak tepat, maka memungkinkan model dan variasi keragaman yang dijelaskan menjadi berkurang. Oleh sebab itu, diperlukan sebuah metode yang tepat dalam penyelesaian data campuran, dan salah satu 
metode yang dapat digunakan untuk menyelesaikan kasus data multivariabel berskala campuran (nominal, ordinal, interval, dan rasio) adalah metode PRINCALS (Analisis Komponen Utama Nonlinear) yang merupakan pengembangan dari Analisis Komponen Utama, yaitu suatu metode/analisis untuk mereduksi variabel dari data multivariabel berskala campuran secara simultan.

METODE PRINCALS (Principal Component Analysis by means of Alternating Least Squares)

PRINCALS merupakan suatu metode yang mampu menganalisis data berskala campuran (nominal, ordinal, rasio dan interval) secara simultan yaitu dengan cara mengelompokkan variabel-variabel yang korelasi linearnya sejalan menjadi satu komponen utama, sehingga dari $\mathrm{p}$ variabel akan didapat $\mathrm{q}$ komponen utama yang saling independen yang masih dapat mewakili keseluruhan persoalan $(q \leq p)$ (Kroonenberg, 2000).

Jika $\mathrm{R}$ adalah matrik korelasi sampel berordo $\mathrm{m} \times \mathrm{m}$ dengan pasangan penaksir akar karakteristik dan penaksir vektor karakteristik yaitu:

$$
\left(\hat{\lambda}_{1}, \hat{e}_{1}\right),\left(\hat{\lambda}_{2}, \hat{e}_{2}\right), \ldots,\left(\hat{\lambda}_{j}, \hat{e}_{j}\right), \ldots,\left(\hat{\lambda}_{m}, \hat{e}_{m}\right)
$$

dan $\tilde{Z}=[Z 1, Z 2, \ldots, Z m]$ observasi yang distandarkan dengan matrik korelasi R, maka penaksir komponen utama ke-j adalah:

$$
\begin{gathered}
\hat{\mathrm{Y}}_{j}=\hat{\widetilde{\mathrm{e}}}_{j}^{\prime} \tilde{\mathrm{Z}}=\hat{\mathrm{e}}_{1 j} \mathrm{Z}_{1}+\hat{\mathrm{e}}_{2 j} \mathrm{Z}_{2}+\cdots+\hat{\mathrm{e}}_{m j} \mathrm{Z}_{m} \quad, \quad \mathrm{j}=1,2, \ldots, \mathrm{m} \\
\text { dimana } \quad \hat{\lambda}_{1} \geq \hat{\lambda}_{2} \geq \ldots \geq \hat{\lambda}_{j} \geq \ldots \geq \hat{\lambda}_{m} \geq 0, \text { dan } \quad \hat{\lambda}_{j} \text { adalah penaksir akar }
\end{gathered}
$$
karakteristik dari matrik $\mathrm{R}$ dan mempunyai sifat tak bias:

$$
\mathrm{E}\left(\hat{\lambda}_{j}\right)={ }^{\lambda_{j}}(3)
$$

PRINCALS di sini didasarkan pada Teori Meet Loss, dengan loss function homogenitas adalah:

$$
\sigma_{M}(\mathbf{X}, \mathbf{Y})=m^{-1} \sum_{j=1}^{m}\left(\mathbf{X}-\mathbf{G}_{j} \mathbf{Y}_{j}\right)^{\prime}\left(\mathbf{X}-\mathbf{G}_{j} \mathbf{Y}_{j}\right)
$$


Program PRINCALS untuk data multivariabel tanpa missing data dapat dilakukan dengan menggunakan regresi linear atau regresi monoton pada semua kategori. Program ini cocok untuk variabel yang berskala nominal, ordinal, interval, dan rasio. Jika data multivariabel tanpa missing data, maka penaksir akar karakteristik dapat dicari dengan cara PRINCALS dari rumus (Gifi,1990):

$\mathrm{m}-1 \mathrm{R}(\mathrm{Q})$

$\mathrm{R}(\mathrm{Q})=$ matrik korelasi antara skor linear gabungan (The linear composite scores) dari semua himpunan matrik Q pada semua dimensi

\section{PENINGKATAN MUTU PENDIDIKAN TINGGI MELALUI IDENTIFIKASI FAKTOR-FAKTOR MEMPENGARUHI PRESTASI BELAJAR MAHASISWA}

Salah satu ukuran mutu sebuah perguruan tinggi adalah kemampuan akademik mahasiswanya, diukur dari nilai IPK yang mereka peroleh. Dunia kerja pun, selalu menjadikannya sebagai salah satu tolak ukur dalam seleksi penerimaan karyawan. Sehingga mau tidak mau, seorang mahasiswa berusaha untuk mencapai nilai IPK minimal 3,0. Terdapat beberapa faktor atau variabel yang diteliti dalam penelitian ini yang berhubungan dengan kondisi responden, diasumsikan memiliki pengaruh terhadap keberhasilan seorang mahasiswa terlepas dari penjaminan mutu sebuah perguruan tinggi. Faktor-faktor tersebut meliputi jenis kelamin, umur masuk, kota asal, nilai NEM, status sekolah, jalur masuk, pekerjaan ayah dan ibu, pendidikan ayah dan ibu, dan status tempat tinggal mahasiswa.

IPK mahasiswa dikategorikan menjadi 3 kelompok yaitu kategori pintar adalah mahasiswa yang memiliki IPK 3,0 keatas, kategori sedang adalah mahasiswa yang memiliki IPK antara 2,5 hingga 3,0, dan kategori kurang adalah mahasiswa yang memiliki IPK 2,5 kebawah. Jumlah responden berdasarkan kategori prestasi belajar tersebut ditunjukkan pada Tabel 1. 
Tabel 1. Pengelompokan tingkat prestasi belajar mahasiswa berdasarkan 3 kategori utama

\begin{tabular}{|c|c|c|c|}
\hline No & Kategori & Jumlah Responden & Persentase \\
\hline 1 & Pintar & 474 & 48,2 \\
\hline 2 & Sedang & 363 & 37,0 \\
\hline 3 & Kurang & 145 & 14,8 \\
\hline \multicolumn{2}{|r|}{ Total } & 982 & 100 \\
\hline
\end{tabular}

Sumber: Hasil olah data, 2010

Selanjutnya, pengelompokkan IPK mahasiswa dilakukan dengan metode KMeans Cluster yang biasa digunakan untuk sampel yang besar. IPK mahasiswa dikelompokkan dengan metode cluster, dengan banyaknya cluster yang dipilih adalah 3 cluster. Pemilihan 3 cluster berdasarkan 3 kategori prestasi belajar yang telah dibuat sebelumnya, yaitu pintar, sedang, dan kurang. Hasil analisisnya ditunjukkan pada tabel berikut.

Tabel 2. Hasil pengelompokkan IPK mahasiswa dengan metode K-Means Cluster

\begin{tabular}{|c|c|c|c|c|}
\hline Cluster & $\begin{array}{c}\text { Rata-Rata } \\
\text { IPK }\end{array}$ & Kategori & Frekuensi & Persentase \\
\hline Cluster 1 & 1,72 & Kurang & 47 & $4,79 \%$ \\
Cluster 2 & 3,30 & Pintar & 434 & $44,20 \%$ \\
Cluster 3 & 2,72 & Sedang & 501 & $51,02 \%$ \\
\hline \multicolumn{3}{|c|}{ Total } & 982 & $100 \%$ \\
\hline
\end{tabular}

Sumber: Hasil olah data, 2010

Hasil pengelompokkan yang ditunjukkan pada Tabel 2, menunjukkan bahwa dari 3 cluster yang terbentuk, rata-rata IPK 1,72 berada pada cluster pertama dengan jumlah mahasiswa sebanyak 47 orang. Cluster kedua terdiri dari 434 mahasiswa dengan rata-rata IPK 3,30, dan cluster ketiga dengan rata-rata IPK 2,72 terdiri dari 501 mahasiswa. Ketiga cluster tersebut, kemudian dapat dikategorikan berdasarkan rata-rata IPK dari masing-masing cluster, yaitu cluster pertama adalah mahasiswa dengan kategori kurang, cluster kedua adalah mahasiswa dengan kategori pintar, dan cluster ketiga adalah mahasiswa dengan kategori sedang.

Uji korelasi yang dilakukan pada setiap variabel menunjukkan bahwa terjadi korelasi antara beberapa variabel bebas yang diteliti (multikolinearitas), sehingga 
diperlukan sebuah analisis untuk mengatasi masalah multikolinearitas tersebut. Data pada penelitian ini merupakan kasus dengan data multivariabel berskala campuran tanpa missing data. Sehingga analisis yang paling tepat digunakan adalah Principal Component Analysis by Means of Alternating Least Squares (Princals) atau analisis komponen utama non linear.

Tabel 3. Proporsi Keragaman yang Dapat Diterangkan oleh Princals

\begin{tabular}{|c|c|c|c|}
\hline Dimensi & Akar Karakteristik & $\begin{array}{c}\text { Proporsi } \\
\text { Keragaman (\%) }\end{array}$ & $\begin{array}{c}\text { Proporsi } \\
\text { Keragaman } \\
\text { Kumulatif (\%) }\end{array}$ \\
\hline 1 & 0,214 & 21,4 & 21,4 \\
\hline 2 & 0,145 & 14,5 & 35,8 \\
\hline 3 & 0,102 & 10,2 & 46,1 \\
\hline 4 & 0,094 & 9,4 & 55,5 \\
\hline 5 & 0,092 & 9,2 & 64,7 \\
\hline 6 & 0,079 & 7,9 & 72,6 \\
\hline 7 & 0,078 & 7,8 & 80,4 \\
\hline 8 & 0,073 & 7,3 & 87,7 \\
\hline 9 & 0,049 & 4,9 & 92,6 \\
\hline 10 & 0,043 & 4,3 & 96,9 \\
\hline 11 & 0,031 & 3,1 & 100,0 \\
\hline
\end{tabular}

Sumber: Hasil olah data, 2010

Nilai akar karakteristik yang ditunjukkan Tabel 3 pada tiap dimensi digunakan untuk menentukan jumlah dimensi yang digunakan dalam analisis. Ukuran nilai akar karakteristik yang digunakan adalah nilai yang lebih besar dari 0,091 (1/jumlah variabel=0,091). Berdasarkan ukuran dari nilai akar karakteristik menunjukkan bahwa akar karakteristik yang lebih besar dari 0,091 sampai pada dimensi 5. Berarti terdapat 5 dimensi yang terbentuk melalui PRINCALS, dengan proporsi keragaman yang dapat dijelaskan secara keseluruhan yaitu sebesar $64,7 \%$. Hasil ini menunjukkan bahwa nilai proporsi keragaman yang dijelaskan dengan Analisis Komponen Utama Nonlinear (PRINCALS) sebesar 64,7\%.

Hasil pengolahan Princals diperoleh lima dimensi variabel baru. Dimensi pertama mampu menjelaskan keragaman sebesar $21,4 \%$ dari total keragaman, dimensi kedua mampu menjelaskan keragaman sebesar $14,5 \%$ dari total keragaman, dimensi ketiga mampu menjelaskan keragaman sebesar 10,2\% dari total keragaman, dimensi keempat mampu menjelaskan keragaman sebesar $9,4 \%$ dari total keragaman, dan dimensi kelima mampu menjelaskan keragaman 
sebesar 9,2\%. Sehingga total keragaman yang dapat dijelaskan jika memilih lima dimensi adalah 92\%. Total keragaman yang mampu dijelaskan Metode Princals lebih tinggi dibandingkan dengan $\mathrm{AKU}$, yaitu sampai lima komponen utama hanya 59,7\% keragaman yang mampu dijelaskan oleh AKU.

Tabel 4. Matrik Komponen Loading Hasil Analisis Komponen Utama PRINCALS

\begin{tabular}{|c|c|c|c|c|c|}
\hline Variabel & Dimensi 1 & Dimensi 2 & Dimensi 3 & Dimensi 4 & Dimensi 5 \\
\hline $\mathrm{X} 2$ & 0,151 & 0,285 & $\mathbf{0 , 6 3 6}$ & $-0,013$ & $-0,060$ \\
\hline $\mathrm{X} 4$ & $-0,082$ & $-0,241$ & $\mathbf{- 0 , 6 4 1}$ & 0,304 & $-0,136$ \\
\hline $\mathrm{X} 1$ & 0,068 & 0,139 & 0,392 & $\mathbf{0 , 7 4 1}$ & 0,054 \\
\hline $\mathrm{X} 5$ & 0,186 & $\mathbf{- 0 , 5 2 7}$ & 0,051 & 0,257 & 0,290 \\
\hline $\mathrm{X} 3$ & $-0,479$ & $\mathbf{0 , 6 5 8}$ & $-0,164$ & $-0,006$ & 0,107 \\
\hline $\mathrm{X} 6$ & $-0,096$ & 0,256 & $-0,058$ & 0,259 & $\mathbf{- 0 , 8 3 1}$ \\
\hline $\mathrm{X} 7$ & $\mathbf{- 0 , 6 6 8}$ & $-0,248$ & 0,059 & 0,221 & 0,108 \\
\hline $\mathrm{X} 8$ & 0,271 & 0,481 & $-0,279$ & 0,430 & 0,317 \\
\hline $\mathrm{X} 11$ & $-0,485$ & $\mathbf{0 , 5 6 4}$ & $-0,096$ & $-0,103$ & 0,279 \\
\hline $\mathrm{X} 9$ & $\mathbf{- 0 , 7 9 8}$ & $-0,226$ & 0,118 & 0,130 & 0,048 \\
\hline $\mathrm{X} 10$ & $\mathbf{- 0 , 8 0 7}$ & $-0,224$ & 0,131 & $-0,044$ & $-0,090$ \\
\hline
\end{tabular}

Sumber: Hasil olah data, 2010

Peningkatan mutu pendidikan tinggi melalui pencapaian prestasi belajar mahasiswa sebagaimana yang diharapkan, maka perlu diperhatikan beberapa faktor yang mempengaruhi prestasi belajar antara lain faktor yang terdapat dalam diri mahasiswa (faktor internal), dan faktor yang terdiri dari luar siswa (faktor eksternal). Berdasarkan hasil dari PRINCALS, maka faktor intern meliputi jenis kelamin, umur, dan nilai NEM, sedangkan faktor eksternal meliputi faktor keluarga, yaitu pendidikan dan pekerjaan orang tua, faktor sekolah, yaitu status sekolah dan jalur masuk perguruan tinggi, dan faktor lingkungan, yaitu asal daerah, dan status tempat tinggal mahasiswa.

Faktor-faktor yang sudah direduksi melalui metode Princals selanjutnya dikelompokkan dengan metode K-Means Cluster. Pengelompokkan ini bertujuan untuk melihat kelompok mahasiswa dengan kondisi yang berbeda-beda, yang perlu diperhatikan oleh pihak perguruan tinggi. Pemilihan jumlah cluster yang dipilih adalah 3 cluster, karena disesuaikan dengan 3 kategori sebelumnya.

Tabel 4 menunjukkan bahwa pengelompokkan tingkat prestasi belajar mahasiswa berdasarkan metode $K$-Means Cluster diperoleh tiga kelompok utama 
mahasiswa. Kelompok yang terbesar jumlah mahasiswanya adalah cluster pertama, yaitu terdapat 606 orang atau sekitar 61,71\%, cluster kedua sebanyak 319 orang atau sekitar 32,48\%, dan cluster ketiga sebanyak 57 orang atau sekitar 5,80\% Hasil ini menunjukkan bahwa kelompok mahasiswa yang harus mendapat perhatian dari perguruan tinggi adalah cluster 1 dan cluster 2 , karena jumlah mahasiswa yang berada dalam cluster tersebut cukup besar. Sehingga perlu dipelajari kondisi-kondisi yang terjadi pada kedua kelompok mahasiswa tersebut, karena hal ini menyangkut dengan prestasi belajar mereka, yang merupakan salah satu ukuran keberhasilan universitas dalam menjalankan pendidikan tinggi.

Tabel 5. Pengelompokan jumlah mahasiswa dengan K-Means Cluster

\begin{tabular}{|c|l|c|c|}
\hline No & Cluster & Jumlah Responden & Persentase (\%) \\
\hline 1 & Pertama & 606 & 61,71 \\
2 & Kedua & 319 & 32,48 \\
3 & Ketiga & 57 & 5,80 \\
\hline \multicolumn{2}{|c|}{ Total } & 982 & 100,00 \\
\hline
\end{tabular}

Sumber: Hasil olah data, 2010

Tabel 6. Hasil ANOVA dari analisis K-Means Cluster

\begin{tabular}{|c|c|c|c|c|c|c|}
\hline & \multicolumn{2}{|c|}{ Cluster } & \multicolumn{2}{|l|}{ Error } & \multirow[b]{2}{*}{$\mathrm{F}$} & \multirow[b]{2}{*}{ Sig. } \\
\hline & Mean Square & df & Mean Square & df & & \\
\hline Jenis Kelamin & .425 & 2 & .225 & 979 & 1.890 & .152 \\
\hline Umur Masuk & 16.769 & 2 & .535 & 979 & 31.361 & .000 \\
\hline Kab/Kota Asal & 5.379 & 2 & .459 & 979 & 11.731 & .000 \\
\hline NEM & 1.072 & 2 & .194 & 979 & 5.520 & .004 \\
\hline Status Sekolah & .617 & 2 & .109 & 979 & 5.643 & .004 \\
\hline Jalur Masuk & 1.213 & 2 & .315 & 979 & 3.855 & .021 \\
\hline Pekerjaan Ayah & 431.757 & 2 & 1.181 & 979 & 365.626 & .000 \\
\hline $\begin{array}{l}\text { Pendidikan } \\
\text { Ayah }\end{array}$ & 321.498 & 2 & .609 & 979 & 528.202 & .000 \\
\hline Pendidikan Ibu & 286.643 & 2 & .743 & 979 & 385.932 & .000 \\
\hline Status Rumah & 6.751 & 2 & .532 & 979 & 12.689 & .000 \\
\hline
\end{tabular}

Sumber: Hasil olah data, 2010 
Hasil ANOVA, menunjukkan bahwa variabel-variabel yang membedakan dalam pembentukan cluster adalah variabel dengan nilai signifikan kurang dari 0,05 (Sig.<0,05). Artinya variabel yang signifikan adalah umur masuk, kabupaten/kota asal, nilai NEM, status sekolah, jalur masuk, pekerjaan ayah, pendidikan ayah, pendidikan ibu, dan status rumah. Berarti terdapat 9 variabel yang dapat dianalisis selanjutnya karena kesembilan variabel tersebut signifikan berpengaruh dalam pembentukan 3 cluster. Nilai $\mathrm{F}$ hitung tertinggi diperoleh pada variabel pendidikan ayah yaitu sebesar 528,202, berarti pendidikan ayah responden sangat berbeda pada setiap cluster. Kemudian disusul pendidikan ibu sebesar 385,932, pekerjaan ayah sebesar 365,626, umur masuk sebesar 31,361, status rumah sebesar 12,689, kab/kota asal sebesar 11,731, status sekolah sebesar 5,643, nilai NEM sebesar 5,520, dan jalur masuk sebesar 3,855.

Faktor yang berpengaruh pada prestasi belajar mahasiswa untuk faktor ekstern meliputi faktor keluarga, sekolah, dan lingkungan. Termasuk di dalamnya, pekerjaan orang tua, pendidikan orang tua, status sekolah, jalur masuk perguruan tinggi, asal daerah, dan status tempat tinggal.

Faktor internal, mencakup umur masuk dan nilai NEM, juga sangat berpengaruh terhadap pencapaian prestasi belajar mahasiswa. Umur masuk yang optimal adalah 18-20 tahun merupakan umur yang mapan dalam menerima kurikulum di bangku perguruan tinggi. Umur masuk dan nilai NEM secara langsung berhubungan dengan faktor intelegensi atau kecerdasan mahasiswa. Kecerdasan adalah kemampuan belajar disertai kecakapan untuk menyesuaikan diri dengan keadaan yang dihadapinya. Kemampuan ini sangat ditentukan oleh tinggi rendahnya intelegensi, intelegensi yang normal selalu menunjukkan kecakapan sesuai dengan tingkat perkembangan sebaya. Seorang secara genetis telah lahir dengan suatu organisme yang disebut intelegensi yang bersumber dari otaknya. Struktur otak telah ditentukan secara genetis, namun berfungsinya otak tersebut menjadi kemampuan umum yang disebut intelegensi, sangat dipengaruhi oleh interaksi dengan lingkungannya (Semiawan, C, 1997). Pada saat bayi lahir ia telah dimodali 100 - 200 milyar sel otak dan siap memproseskan beberapa trilyun informasi. Cara pengelolaan intelegensi sangat mempengaruhi kualitas manusianya, tetapi perlakuan lingkungan dalam caranya 
tidak selalu menguntungkan perkembangan intelegensi yang berpengaruh terhadap kepribadian dan kualitas kehidupan manusia. Ternyata dari berbagai penelitian bahwa pada umumnya hanya kurang lebih 5\% neuron otak berfungsi penuh (Clark, 1986).

Berdasarkan hasil uji $K$ Means Cluster, perhatian pertama harus diperuntukkan pada cluster pertama yaitu mahasiswa dari luar kota yang tinggal di kontrakan. Dimana rata-rata pekerjaan orang tua sebagai petani dan wiraswasta, sehingga kelompok mahasiswa ini dapat dikategorikan sebagai mahasiswa dengan keluarga yang memiliki ekonomi lemah. Artinya permasalahan pokok pada cluster pertama yang harus diperhatikan adalah faktor ekonomi lemah dengan mahasiswa yang berasal dari luar kota.

Perhatian kedua diperuntukkan pada cluster kedua yaitu mahasiswa yang juga berasal dari luar kota tetapi memiliki orang tua dengan pekerjaan di lembaga pemerintahan dan karyawan swasta atau BUMN. Artinya, permasalahan pokok pada cluster kedua ini bukan dari segi ekonomi, malah sebaliknya, orang tua mereka mampu menyediakan segala fasilitas yang mereka butuhkan, sehingga memungkinkan untuk melakukan banyak hal di luar kampus akibat pengaruh dari kehidupan perkotaan dan lingkungannya, sehingga membuat mahasiswa tidak memperhatikan lagi kuliahnya.

\section{KESIMPULAN}

1) Hasil uji ANOVA dalam metode Princals, diperoleh faktor-faktor yang berpengaruh terhadap prestasi belajar adalah umur masuk, nilai NEM, status sekolah, jalur masuk, pekerjaan ayah, pendidikan ayah, pendidikan ibu, dan status tempat tinggal.

2) Prioritas pertama yang harus diperhatikan perguruan tinggi dalam meningkatkan prestasi belajar mahasiswa adalah mahasiswa yang berasal dari luar kota dengan kondisi ekonomi lemah, ditandai dengan pekerjaan orang tua adalah petani dan wiraswasta.

3) Prioritas kedua yang harus diperhatikan lagi oleh pihak perguruan tinggi adalah kelompok mahasiswa yang juga berasal dari luar kota, dan sebagian dari dalam kota dengan kondisi ekonomi yang lebih mapan, ini ditandai dengan pekerjaan orang tua di lembaga pemerintahan dan karyawan swasta/BUMN.

4) Pendidikan tinggi di Indonesia harus terus meningkatkan mutunya sehingga dapat bersaing dengan perguruan tinggi di tingkat internasional. Faktor internal dan eksternal yang telah diperoleh melalui Princals, menunjukkan bahwa banyak fakta- 
fakta yang harus dikaji dari diri mahasiswa sebagai salah satu unsur civitas akademika di perguruan tinggi, guna penetapan kebijakan dalam peningkatan mutu perguruan tinggi. Lingkungan pendidikan dan berbagai pusat pelatihan serta tempat kerja sekarang ini, telah dipengaruhi oleh lingkungan global yang merupakan berbagai pengaruh eksternal dalam dinamika berbagai aspek kehidupan di dunia. Kehidupan komunitas global menuntut adaptasi masyarakat pada kondisi global dan pada gilirannya menuntut adaptasi individu untuk bisa bertahan di masyarakat di mana ia hidup dan peran perguruan tinggi sangat dibutuhkan.

\section{DAFTAR PUSTAKA}

[1] Agresti, A. (2006), An Introduction to Categorical Data Analysis, John Wiley \& Sons. Inc, New York.

[2] Bolton, R.J., Krzanowski, W.J. (1999), A Characterization of Principal Components for Projecton Pursuit, The American Statistician, Vol.53, No.2, 108-123.

[3] Gifi, A. (1990), Nonlinear Multivariate Analysis, Chichester, UK: Wiley.

[4] Korhonen, P., Siljamaki, A. (2000), Ordinal Principal Component Analysis Theory and an Application, Computational Statistics and Data Analysis vol. 26, 411-424.

[5] Kroonenberg, P.M., Harch, B.D., Basford K.E., and Cruickshank, A. (2000),Combined Analysis of Categorical and Numerical Descriptors of Australian Groundnut Accessions Using Nonlinear Principal Component Analysis, Journal of Agricultural, Biological, and Environmental Statistics, Vol.2, No.3, 294-312.

[6] Shmueli, G., Cohen, A., (1999), Analysis and Display of Hierarchical Life-Time Data,The American Statistician, Vol.53, No.2, 140-152.

[7] Siswadi, Suharjo, B. (1999), Analisis Eksplorasi Data Peubah Ganda, Jurusan Matematika FMIPA IPB, Bogor.

[8] Slameto (2003), Belajar dan Faktor-faktor yang Mempengaruhinya, PT. Rineka Cipta, Jakarta.

[9] Vichi, M. (1997), Principal Classifications Analysis: A Method for Generating Concensus Dendograms and Its Application to Three-way Data, Computational Statistics and Data Analysis vol. 27, 311-331.

\section{KEMBALI KE DAFTAR ISI}

